Nowoczesne Systemy Zarządzania

Zeszyt 14 (2019), nr 3 (lipiec-wrzesień)

ISSN 1896-9380, s. 113-122

Modern Management Systems

Volume 14 (2019), No. 3 (July-September)

ISSN 1896-9380, pp. 113-122
Instytut Organizacji i Zarządzania

Wydział Bezpieczeństwa, Logistyki i Zarządzania

Wojskowa Akademia Techniczna

w Warszawie

Institute of Organization and Management Faculty of Security, Logistics and Management Military University of Technology

\title{
Threats and ensuring information security in crisis management systems
}

\section{Zagrożenia i zapewnianie bezpieczeństwa informacyjnego w systemach zarządzania kryzysowego}

\author{
Michał Jurek \\ Military University of Technology \\ Faculty of Security, Logistics and Management \\ Marcin Staruch \\ Military University of Technology \\ Faculty of Security, Logistics and Management
}

\begin{abstract}
Constantly progressing technical and technological development has allowed the creation of IT tools, the use of which will positively affect the actions taken by decision-makers. However, in order to be able to use them properly, in addition to thoroughly familiarizing themselves with their capabilities, it is necessary to develop operating schemes, e.g. human management, taking into account the use of the tools discussed in the article. When creating appropriate solutions, special attention should be paid to the possibility of securing information and data on which we will operate. This will be especially important during a crisis situation such as a flood, for example, where properly coordinated actions will allow a more effective rescue action. This will translate into lowering material and human losses. It should be remembered, however, that IT tools should always play a supporting role, and all decisions should be made after their prior assessment by a suitably qualified person.
\end{abstract}

Keywords: flood, blockchain, management.

Abstrakt. Ustawiczny rozwój techniczno-technologiczny umożliwił opracowanie narzędzi informatycznych, których wykorzystanie może pozytywnie wpływać na działania podejmowane przez decydentów. Jednakże, chcąc z nich prawidłowo korzystać, oprócz dokładnego zapoznania się z ich możliwościami, konieczne jest opracowanie i rozwijanie schematów operacyjnych, np. zarządzania ludźmi, z uwzględnieniem wykorzystania narzędzi informatycznych opisanych w artykule. W trakcie tworzenia odpowiednich rozwiązań należy zwrócić szczególną uwagę na możliwość zabezpieczenia informacji i danych, na których wykonywane są operacje. Będzie to szczególnie ważne w sytuacji kryzysowej, takiej jak np. powódź, gdy odpowiednio skoordynowane działania pozwolą na skuteczniejsze działania ratownicze. Może się to 
przełożyć na obniżenie strat materialnych i ludzkich. Należy jednak pamiętać, że narzędzia informatyczne powinny zawsze odgrywać rolę pomocniczą, a wszystkie decyzje muszą być podejmowane po ich uprzedniej ocenie przez odpowiednio wykwalifikowaną osobę.

Słowa kluczowe: powódź, blockchain, zarządzanie.

\section{Introduction}

Flood is one of the most frequently occurring natural hazards and is a natural phenomenon of an elementary, often violent, occurring irregularly (Powodz, 2019). According to art. 16 point 43 of the Water Law Act of 20 July 2017, the flood is defined as "temporary covering by water of land, which under normal conditions is not covered with water, in particular caused by water surges in natural water courses, water reservoirs, canals and from the sea, excluding water coverage of land caused by water spurt in sewage systems" (Water Law, 2019, p. 15). The phenomenon of flooding can be presented in the form of 4 phases: water supply, wave (climax), water falling, return to normal. Therefore, the flood process is illustrated by figure 1 and types of flood due to the source of occurrence are illustrated by figure 2 (Simpson, 2004, p. 5).

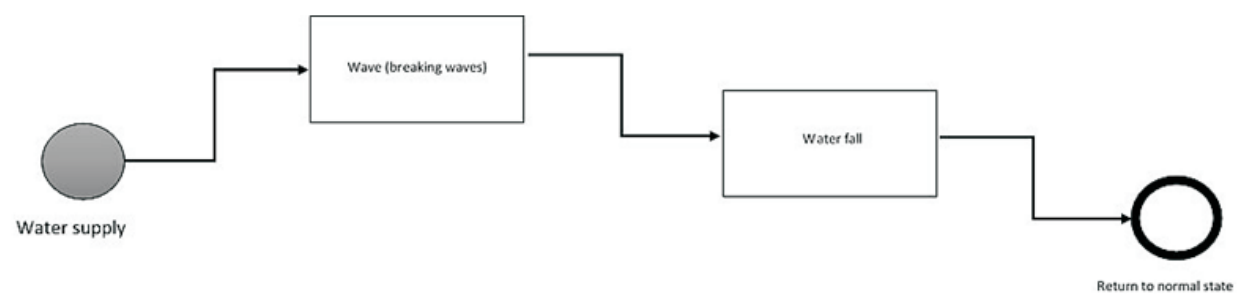

Fig. 1. Flood phases

Source: own elaboration

Types of flood due to the source of occurrence are as follows:

- River flood - relates to water rivers, streams, canals, mountain streams, lakes, as well as snow melting.

- Rain flood - a flooding the area with waters that come from rainfall or melting snow. It may include urban brewing floods or excess water in nonurban areas.

- Flooding from groundwater - this is flooding of the area as a result of rising water level above ground level. The effect of this flood is the rise of ground and underground water as a result of a high level of surface waters.

- Flood from the seaside - it relates to flooding of the terrain by sea waters, including also estuarine sections of coastal lakes and rivers.

- Flood from hydrotechnical facilities - it is flooding of the land resulting from failures of building dams (Grocki, 2020, p. 76). 


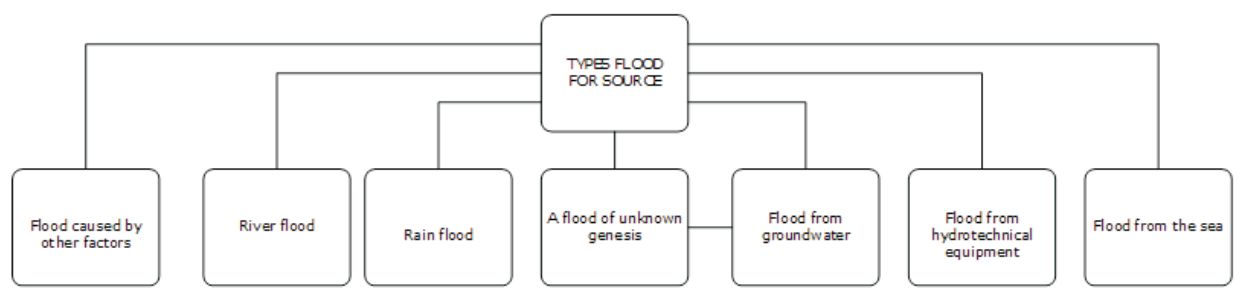

Fig. 2. Types of floods by the source of occurrence

Source: own elaboration based on (Powodz, 2019)

Types of floods due to the mechanism are as follows:

- Natural fry - occurs as a result of rising water level.

- Overflow of water - occurs as a result of flooding due to overflow of water through the flood embankment crown.

- Building failure - occurs as a result of destruction or damage to artificial or natural flood protection or as a result of failure of retention facilities or flood gates.

- Embolic flood - occurs when an artificial or natural blockage on the watercourse occurs.

In the event of a flood hazard, the first stage of the preliminary flood risk assessment (WOPR) is performed. The aim of WOPR is to designate areas that are exposed to flood (ONNP), so areas where there is a high risk of flooding or where the occurrence of such a risk is very likely. Flood risk assessment is performed based on information that is available and easy to obtain.

Based on the preliminary flood risk assessment, we can therefore determine: areas exposed to danger, flood hazard maps, flood risk maps, flood risk management plans. Areas that are exposed to the risk of flood occurrence are determined during the preliminary flood risk assessment and for the purposes of the WOPR it is not necessary to designate a precise area at risk of flooding, its initial identification. Subsequent documents of the planning cycle define precise areas, which are presented on flood risk maps (MZP) and on flood risk maps (MZR), and on their basis, flood risk management plans (FRMP) are developed.

\section{New methods of eradicating the flood}

Having the opportunity to determine a precise area of flood risk, we can develop an appropriate action plan to compensate for or reduce the effects of floods. In order to improve the operation of rescue services, the aim of which is to prevent and eliminate the effects of floods, various types of exercises are carried out to properly prepare for situations occurring in the real environment. These types of exercises should be divided into at least two parts: theoretical part and practical part. 
The first part, and therefore the theoretical one, should contain basic rules of conduct in the event of a threat, discussion of health and safety rules, and should contain the main goals to achieve along with information about available equipment and methods of obtaining it and allocation of individual roles to relevant services. After presenting the theoretical part, the next step should be to familiarize the services with the available equipment. Considering the fact that flooding is a threat that is often encountered with and difficult to control, it is worth considering new methods of improving and combating this element. The second stage of this type of exercise is a practical part aimed at practicing crisis situations in natural conditions in order to better prepare the services in the event of a threat. In the event of flooding, time plays a major role, and acting under the pressure of time often introduces a lot of disorientation and lack of proper organization. The use and implementation of mobile solutions to fight the element can thus significantly facilitate the operation of emergency services. Taking into account the fact that often the struggle takes place in various areas, it is worth answering the question: "How to manage people we do not see?". So that the action is more efficient and more effective. The answer to this type of question is asked not only by many managers in enterprises, but also people facing the problem of deployment of people in a short time, in specific places, with appropriate communication equipment (mobile phone or laptop). Despite technological development, effective communication with people in different places is a huge challenge.

In the case of threats such as: natural, unnatural, technical or war, we often encounter a situation in which decisions to reduce or reduce losses must be made at a rapid pace, and the only form of communication is a mobile phone or a laptop. Given the fact that these types of people can be many, and it is impossible to connect with them at the same time or talking with them can significantly extend the intervention time, I think that it is worth considering a unified human management system. Therefore, one should consider what form of communication between people will be the most appropriate in this case and choose the most effective way of passing on the orders.

Therefore, commanding, and hence the command style, which involves constant monitoring and control of employees and issuing appropriate instructions to them, whose implementation must be performed in accordance with the instructions of the person issuing them, can be used for proper management of people in crisis situations. This type of style is suitable for crisis situations and works great in them due to the fact that there is no room for the initiative, creativity and creativity of the employee, and the tasks are performed quickly and correctly. In order for all kinds of activities to take place in a dynamic way, an appropriate manager should be selected for this type of exercise, who will know what the steering action cycle is and will put it right - planning, controlling and organizing the management. In order to check what effect, the modern technology has to influence the quality of flood 
control measures, it is necessary to divide the persons participating in the exercise into two groups:

- Group 1 - a group using the existing method methods;

- Group 2 - a group equipped with mobile equipment, to which messages and instructions regarding tasks that were placed on a person participating in the exercise will be sent. This group, equipped with mobile devices, adheres to short messages to verify work and provide information on possible complications or hardware shortages. Questions asked by the supervisor should therefore be short and refer to the crisis situation.

On opposite sides of the shaft are placed two groups:

- Group 1, which will use the existing methods;

- Group 2 correlating with modern methods.

One of the groups will receive the word-for-word assignments before starting the exercise. The second group will receive information via mobile devices directly from the place where the exercise is carried out (Żeliński, 2017, pp. 33-56). The above task is aimed at checking which group will behave better in a crisis situation. Group 1 performing its work according to standard procedures or group 2 receive information on the phone (see fig. 3 ).

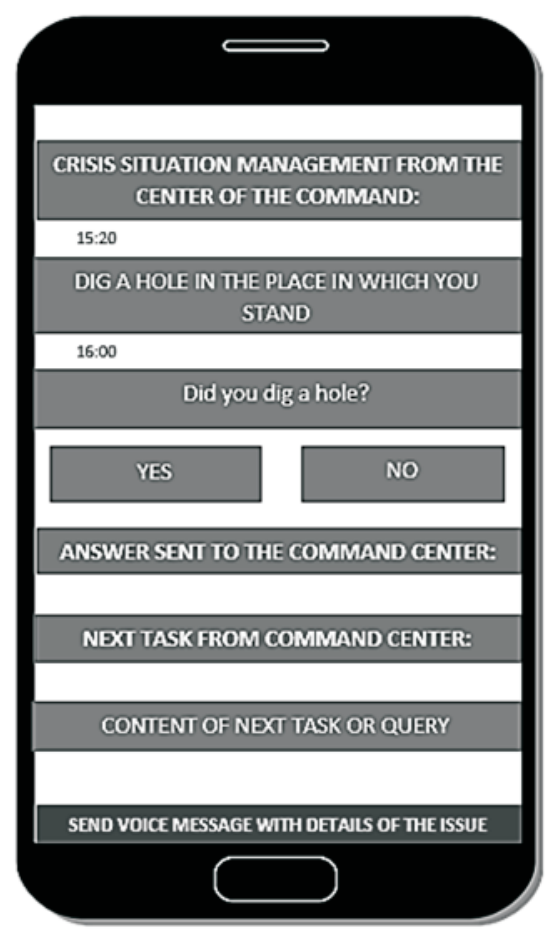

Fig. 3. Mobile application prototype Source: elaboration based on (Rysz, 2017, p. 81) 
The above figure shows the prototype of the application for communication in crisis situations. The application contains simple questions about the tasks to be carried out by persons queuing from mobile devices. In addition, the device user has the option of recording a voice message with a short description of the problem, which will then be sent to the Crisis Management Centre (Gawin, Marcinkowski, 2013, p. 25). So how should information about tasks to be done look like? The simplest way to present this type of tasks is through business processes (see fig. 4).

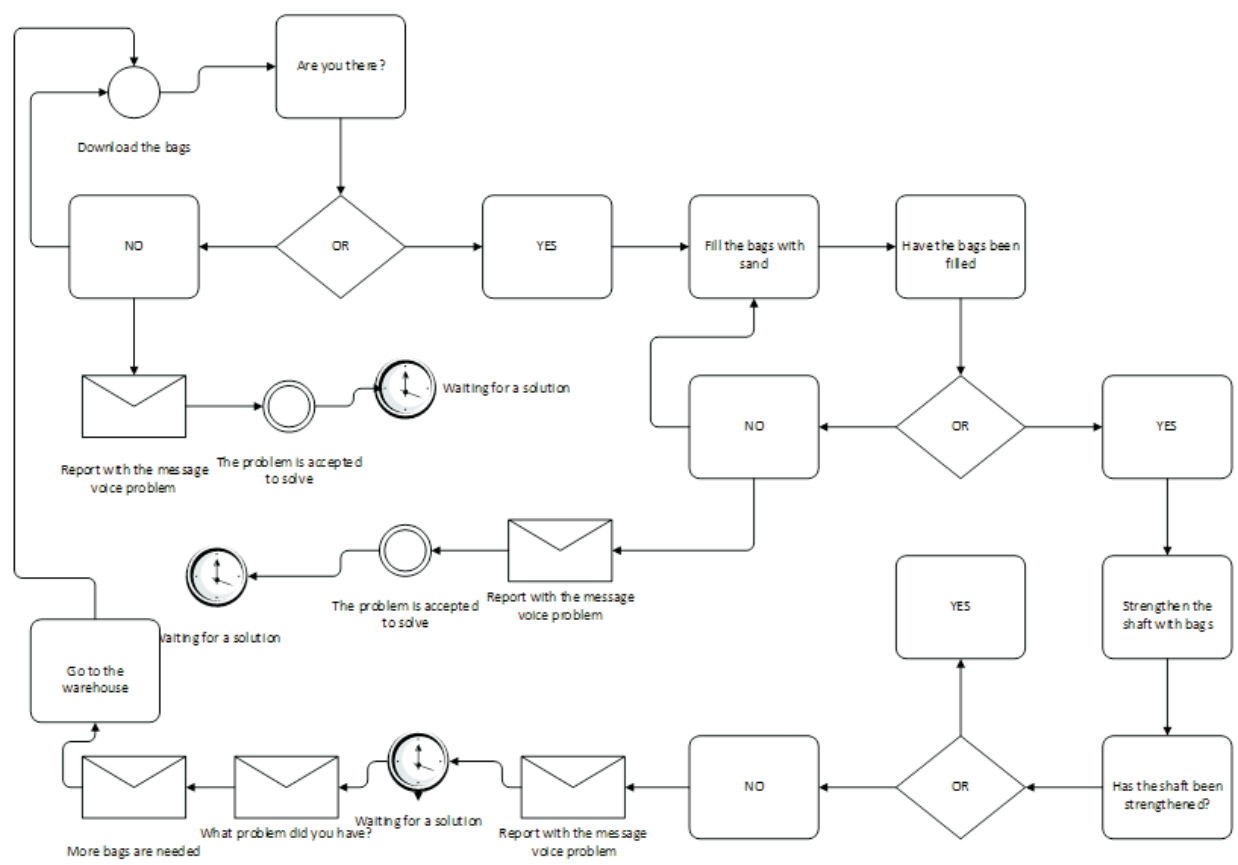

Fig. 4. BPMN model how to act during flood

Source: own elaboration

As it can see from the model, it can be done a set of procedures to facilitate the management of people that we do not see and prepare them a ready-made scheme of random events (Aguilar-Saven, 2004, pp. 129-149), and to reduce the risk of scattering the employee performing our activities, configure mobile devices in such a way that they do not they are unnecessary applications and the only function they would be equipped with would be to save lives. In order for this type of activity to be carried out, it is necessary to limit the mobile device, i.e. not to equip it with a SIM card, a separate way of communication via Bluetooth or WIFI. This type of solution gives you additional pluses in the form of independence from providers. In the event of a threat, we may encounter the problem that the communication 
will be broken. In this case, continuity of operation must be ensured in an appropriate manner. Therefore, it should be considered to create your own method of communication in a separate network without access to the Internet, whose main task would be to broadcast messages and tasks adequate to the occurrence. It is worth asking yourself here how such a network will work in an emergency, how safe it is, and how much coverage we can achieve, however, to answer such questions it is necessary to conduct appropriate research. The only doubt that arises at this stage concerns adequate protection of this type of solution in such a way that it is safe enough to prevent unauthorized persons from accessing it. For this purpose, it is worth considering using the Blockchain method.

\section{Securing information flow}

In today's heavily computerized world, more and more information are being sent electronically. This was due to rapid technical and technological progress in the field of ICT. The developed hardware tools and the software developed for their operation significantly shortened the distance and time of data transmission between the sender and the recipient. The blurring of these boundaries and the increasing role of the Internet network in everyday life led to a significant increase in the data generated and transmitted (see fig. 5).

\section{Intist whathathopersinan}

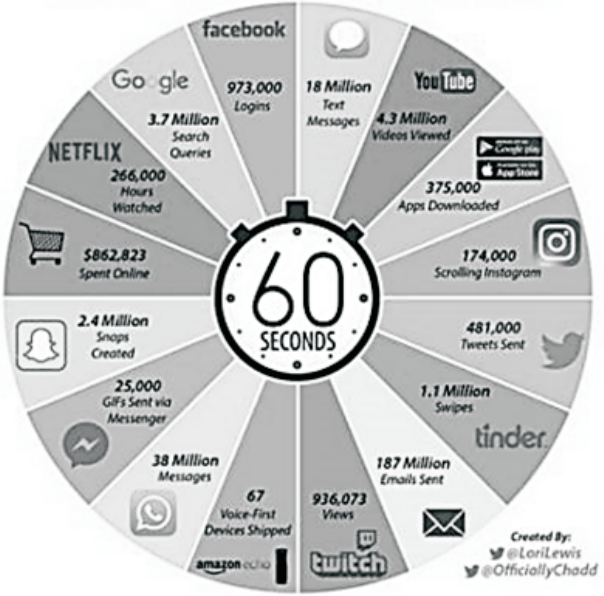

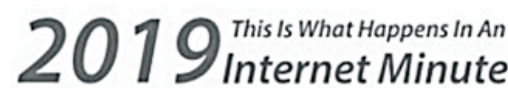

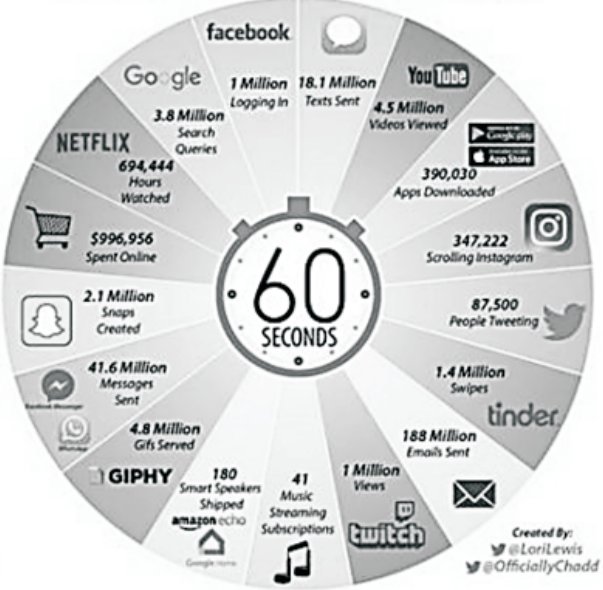

Fig. 5. Sixty seconds of data flow in the Internet Source: elaboration based on (Being Guru, 2019) 
As it can be seen, the use of the Internet by the user (citizen) has mainly a social or entertainment dimension. However, it can also be used in the business sphere the use of various types of information systems to support organization (in the form of internet applications). Rapid growth of generated information and data and their different use possibilities will translate into an increase in their importance as a strategic advantage, which should be adequately protected. These safeguards should relate to the features of information that guarantee its fulfilment of its role. These features are: relevancy, accuracy, timeliness, completeness, consistency, and reliability (Liderman, 2017, p. 16). They determine the quality of information. It affects the possibility of using data or information in professional (business) applications. Information that could be used, for example, when creating business processes must be of appropriate quality (characterized by the above-mentioned attributes) (Liderman, 2017, pp. 17-18).

Nowadays information protection focuses on ensuring trust in the entities that process them. However, the constant and rapid development of tools for the handling (manipulation) of data and information causes a significant decrease of a trust level. This is dictated by the increased possibilities of attacking the central data processing entity. To avoid a crisis of confidence, consider moving from a centralized (network) structure to a decentralized network (see fig. 6).

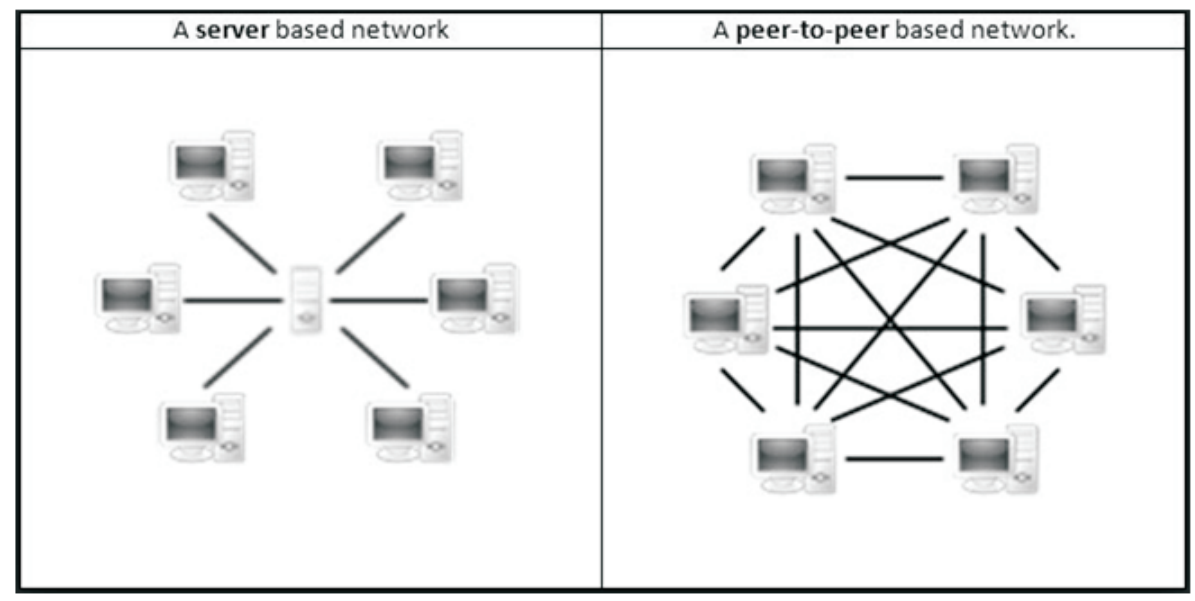

Fig. 6. Centralized and decentralized network pattern

Source: elaboration based on (BitcoinWiki, 2019)

Blockchain technology, which bases its operation on a decentralized structure (P2P network), can be a solution to help solve the crisis of confidence. It is a young IT tool (created in 2008), which allows you to record operations carried out in one chain (chain), whose individual links are connected with each other by means of a cryptographic hash function (Dhillion, Metclaf, Hooper, 2018, p. 22). This is illustrated by figure 7 . 
Blockchain is a kind of accounting book in which transactions can take various forms, e.g. exchange of currency or even a digital signature (Dhillion, Metclaf, Hooper, 2018, pp. 25-26). The use of this technology to secure transmitted data during the emergence of a crisis situation (and in particular floods) will be a key factor influencing the quality of the work of crisis management teams. It will allow adequate security of transmitted information (orders) against unauthorized access by third parties even in the absence of communication with the public Internet network, because this solution can also be implemented in ad hoc local networks (Mougayar, 2019, pp. 32-36). The invariability of information stored with the use of block chain technology will also support the evaluation of actions taken, which will translate into the development of better crisis management plans and the assessment of the rescue operation in terms of effectiveness of its implementation.

\section{HOW BLOCKCHAIN WORKS}

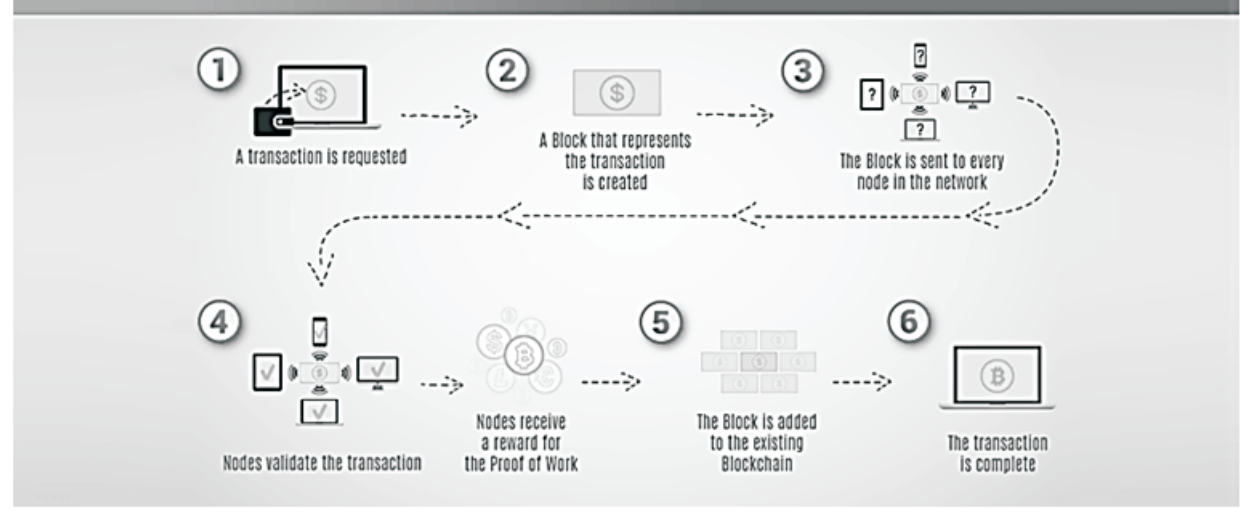

Fig. 7. Simple scheme how Blockchain works

Source: (Zignuts Technolab, 2019)

\section{Conclusions}

In the era of digitization the using of new technologies to provide security for citizens is a kind of necessity. In addition to the use of appropriate IT tools for this purpose, appropriate management methods should also be developed, for example people who are constantly connected to the Internet or local networks. Without these two important variables, decision-makers will not be able to use the full potential of the synergy of technology with the creativity of the individual - human. 


\section{BIBLIOGRAPHY}

[1] Act Water Law, 2017 - Ustawa z dnia 20 lipca 2017 r. - Prawo wodne (DzU 2017 poz. 1566).

[2] Aguilar-Savén R.S., 2004, Business Process Modelling: Review and Framework, "International Journal of Production Economics", Vol. 90, No. 2.

[3] Dhillion V., Metcalf D., Hooper M., 2018, Blockchain Technology Applications, Wydawnictwo Naukowe PWN, Warszawa.

[4] Gawin B., Marcinkowski B., 2013, Symulacja procesów biznesowych. Standardy BPMS i BPMN w praktyce, Wydawnictwo Helion, Gliwice.

[5] Grocki R., 2020, Zarządzanie kryzysowe dobre praktyki, Wydawnictwo Difin, Warszawa.

[6] Liderman K., 2017, Bezpieczeństwo informacyjne. Nowe wyzwania, Wydawnictwo Naukowe PWN, Warszawa.

[7] Mougayar W., 2019, The Business Blockchain: Promise, Practice, and Application of the Next Internet Technology, Wydawnictwo Helion, Gliwice.

[8] Rysz S.J., 2017, Ostrzeganie, alarmowanie, powiadamianie ratunkowe, Wydawnictwo Difin, Warszawa.

[9] Żeliński J., 2017, Analiza biznesowa. Praktyczne modelowanie organizacji, Wydawnictwo Helion, Gliwice.

\section{INTERNET SOURCES}

[1] BitcoinWiki, 2019, Peer-to-Peer (access: 15.05.2019), https://en.bitcoinwiki.org/wiki/Peer-to-peer.

[2] Ikram S., What Happens on Internet in 60 Seconds (one minute) in 2019? (access: 15.05.2019), https://www.beingguru.com/2019/06/what-happens-on-internet-in-60-seconds-one-minute-in-2019/.

[3] PowóDź, 2019, Powódź: definicja i typy (access: 15.05.2019), http://powodz.gov.pl/pl/definicja-i_typy.

[4] Simpson R.C., 2004, Volume 1 - NTRS - NASA (access: 15.05.2019), https://ntrs.nasa.gov/archive/ nasa/casi.ntrs.nasa.gov/20050202022_2005202152.pdf.

[5] Zignuts Technolab, 2019, How Blockchain Architecture Works? Basic Understanding of Blockchain and its Architecture (access: 15.05.2019), https://www.zignuts.com/blogs/how-blockchainarchitecture-works-basic-understanding-of-blockchain-and-its-architecture/. 